Fikrah: Jurnal Ilmu Aqidah dan Studi Keagamaan

ISSN 2354-6147 EISSN 2476-9649

Tersedia online di: journal.stainkudus.ac.id/index.php/fikrah

DOI: 10.21043/fikrah.v5i1.2068

\title{
Muslim Puritan Dan Muslim Moderat (Pembacaan Terhadap Kedudukan Perempuan)
}

\author{
Munawir \\ IAIN Purwokerto \\ munawir.0510@gmail.com
}

\begin{abstract}
Abstrak
Muslim puritan-dengan semangat kembali pada al-Quran dan Sunnah menjadikan Islam pada masa Nabi saw sebagai model yang otentik dan Final. Dengan pendekatan tekstualis, mereka memahami Islam secara rigid sehingga segala tampilan Islam yang bercampur dengan lokalitas setempat (non-Arab) harus disterilisasi supaya murni kembali. Berbeda dengan muslim moderat, sekalipun mempunyai faham yang sama kembali pada al-Quran dan sunnah, namun tidak menggunakan pendekatan tekstualis tetapi menggunakan pendekatan kontekstualis ataupun filosofis. Kajian ini didasarkan pada kajian kesejarahan dengan pendekatan deskriptif-kualitatif. Islam pada masa Nabi saw dipandang oleh muslim moderat sebagai Islam yang mampu berdialektika dengan sosio-kultur masyarakatnya, karena mereka memahami Islam secara lentur dan fleksibel. Dengan pendekatan yang berbeda dalam gerak kembali pada al-Quran dan Sunnah menyebabkan episteme ber-Islam kedua kelompok ini berbeda, sebagaimana tampak pada isu kedudukan perempuan. Hanya saja dalam panggung sejarah, kelompok muslim puritan seringkali menggunakan cara kekerasan atas nama agama untuk mempertahankan dan menyebarkan ideologinya.
\end{abstract}

Kata kunci: Puritan, Moderat, Wahabi, Salafi, Kedudukan Perempuan. 


\begin{abstract}
Puritan Muslim and moderate Muslims (Readings on the Women Status). Puritans Muslim -with a spirit of the Quran and Sunnah- made Islam in the time of Prophet Saw as an authentic and final model. Using a textual approach, they understand Islam rigidly so that all the features of Islam mixed with local locality (non-Arabic) are considered to be viruses and must be sterilized to get pure. In contrast to moderate Muslims, though both of them are in line with the Qur'an and Sunnah, they are not using a textual approach but contextualist or even philosophical. Islam at the time of the Prophet saw was viewed by moderate Muslims as a historic and dialectical Islam with socio-cultural society, because they understand Islam flexibly. With different approaches in the return movement in the Quran and Sunnah, the two Islamic epistemes are different, as seen in the issue of women's position. In the history, Puritan Muslims often use violence in the name of religion to defend and spread its ideology. The above study is based on historical study with descriptive-qualitative approach.
\end{abstract}

Keywords: Puritan, Moderate, Wahabi, Salafi, Female Position.

\title{
Pendahuluan
}

Pembaruan pemikiran Islam sepertinya tidak pernah berhenti. Upaya untuk memahami dan membumikan pesan-pesan Allah (baca: Islam) terus berlangsung. Tentu ada pasang surutnya. Setiap sejarah memiliki periode kejayaannya masingmasing yang berbeda satu generasi ke generasi yang lainnya. Paling tidak, dalam pergulatan sejarah pemikiran Islam, secara umum ada dua corak pemikiran yang saling berlawanan, yaitu Islam puritan dan Islam moderat. Masing-masing aliran memiliki konsturksi epsitemologi keilmuan dalam mempertahankan argumentasinya. Ada dua persoalan utama yang membedakan Islam puritan dan Islam moderat, yang dua hal itu terangkum dalam rumusan pertanyaan: Pertama, apakah teks-teks keagamaan ditujukan untuk mengatur segala aspek kehidupan? Kedua, apakah estetika (kemampuan bawaan manusia) untuk berpikir secara cermat dan mengetahui 'sesuatu yang baik' itu dimungkinkan? Pertanyaan tersebut akan dikaji untuk menemukan sumber otoritatif yang dipahami oleh kelompok interpretasi.

Kedua golongan-apakah puritan atau moderat-pada dasarnya masih berada dalam bingkai agama yang sama, namun karena keduanya memeluk pandangan dunia (world view) yang secara mendasar berbeda, maka respon terhadap dua rumusan pertanyaan menjadi titik tolak perbedaan antar keduanya. Dalam pandangan Izutsu, 
pandangan dunia menjadi penting karena dikonstruk dari pemahaman seorang (Izutsu, 2004). Selanjutnya, dari pandangan dunia yang berbeda tersebut akhirnya juga berdampak pada cara pandang keduanya terhadap isu-isu aktual seperti isi kedudukan perempuan.

Pada dasarnya dalam dunia modern Islam ada banyak istilah yang bisa digunakan sebagai sinonim dari istilah puritan. Di antaranya adalah istilah fundamentalis. Namun, banyak sarjana mengakui bahwa penggunaan istilah fundamentalisme adalah problematik. William Montgomery Watt (1997, hal. 3-4) mengatakan bahwa istilah fundamentalisme pada dasarnya merupakan suatu istilah Inggris kuno yang ditujukan kepada kalangan Protestan yang berpandangan bahwa alKitab harus diterima dan ditafsirkan secara harfiah. Definisi fundamentalisme Islam dengan kelompok muslimin yang sepenuhnya menerima pandangan dunia tradisional serta berkehendak mempertahankannya secara utuh, karena setiap istilah memiliki konotasi atas perilaku dan makna yang ditetapkan.

Rahman (2000, hal. 14) menggunakan istilah revivalisme, mendefinisikan fundamentalisme dengan orang-orang yang memiliki komitmen terhadap proyek rekonstruksi atau pemikiran kembali Islam salaf atau ortodoksi. Sementara itu, Tibi (2000, hal. 23) mendefinisikan fundamentalisme bukan sebagai kepercayaan spiritual, tetapi sebagai ideologi politik yang didasarkan pada politisasi agama untuk tujuantujuan sosio-politik dan ekonomi dalam rangka menegak tatanan yang diridhai Allah.

Selanjutnya, letak problematik istilah fundamentalisme semakin tampak jelas dalam pandangan Khalid Abou el-Fadl (2006, hal. 29). Istilah fundamentalisme mengandung ambiguitas dalam pengertiannya. Fundamentalis sering diidentikkan dengan Islam garis keras, padahal dalam bahasa Arab istilah itu dikenal dengan alushuli yang berarti seseorang yang bersandar pada hal-hal yang bersifat pokok dan mendasar. Makna ini senada dengan makna fundamentalis dalam bahasa Inggris, yaitu fundament yang artinya dasar dari sesuatu atau sesuatu yang asasi (Nurhakim, n.d., hal. 148). Dalam koridor ini, dapat dikatakan bahwa semua kelompok dan organisasi Islam berpijak pada ajaran-ajaran fundamental Islam, bahkan kelompok paling liberal pun; mereka akan menegaskan bahwa cita-cita dan pendirian mereka adalah 
merepresentasikan ajaran-ajaran fundamental Islam. Contoh kongkrit dari hal ini adalah buku karya Hasan Hanafi, Aku Bagian dari Fundamentalisme Islam. Di sinilah letak ketaksaan istilah fundamentalis itu.

Berdasarkan pertimbangan beberapa kajian terdahulu, kiranya penulis lebih memilih istilah yang digunakan oleh Khalid Abou el-Fadl yaitu puritanisme daripada istilah fundamentalisme untuk merepresentasikan kelompok minoritas umat Islam yang militan dan fanatik, karena ciri menonjol kelompok ini dalam hal keyakinannya menganut paham absolutisme dan tidak kenal kompromi. Dalam banyak hal, orientasi kelompok ini cenderung menjadi puris, dalam arti ia tidak toleran terhadap berbagi sudut pandang yang berkompetisi dan memandang realitas pluralis sebagai satu bentuk kontaminasi atas kebenaran sejati.

\section{Puritanisme; antara Ideologi Wahabi dan Salafi}

\section{Asal-Usul Wahabi}

Sejarah origin puritan bisa dimulai dari kaum Wahabi. Hal ini karena kaum Wahabi telah benar-benar mempengaruhi setiap gerakan puritan dunia Islam di era kontemporer. Setiap kelompok Islam yang sudah dilekati citra buruk oleh dunia internasional, seperti Taliban dan al-Qaida, sangat kuat dipengaruhi oleh pemikiran Wahabi. Meskipun pada era kontemporer makna puritan tidak hanya menunjukkan pada paham wahabi, tetapi secara ideologis terma tersebut mempunyai kaitan yang erat dengan Wahabi.

Adapun dasar-dasar ideologi Wahabi dibangun oleh seorang fanatik abad ke-18 yaitu Muhammad bin Abdul Wahhab (1115-1201 H/1703-1787 M). Ia lahir di Yainah, Najed, wilayah yang berada di tengah padang pasir daratan Arab (Najib, 2009, hal. 3). Gagasan utama Abdul Wahhab adalah bahwa umat Islam telah melakukan kesalahan dengan menyimpang dari jalan yang lurus dan hanya dengan kembali ke satu-satunya agama yang benar mereka akan diterima dan mendapat ridha Allah (Khaled M.Abou el, 2006). Dengan semangat puritan Abdul Wahhab hendak membebaskan Islam dari semua perusakan yang diyakininya telah menggerogoti agama Islam yang di antaranya tasawuf, rasionalisme, dan praktik-praktik lain yang dinilainya sebagai inovasi bid'ah. 
Pada masa Abdul Wahhab, modernitas telah merevolusi konsepsi manusia mengenai realitas di dunia dengan memperkenalkan konsep yang mengguncangkan kesadaran, yakni konsep relativitas dan empirisisme ilmiah. Di kalangan tertentu umat Islam dewasa ini ada yang beranggapan bahwa pengaruh Eropa atas dunia Islam adalah bermula dari pecahnya perang Salib. Memang, pada taraf tertentu pandangan ini dapat dibenarkan, akan tetapi pengaruh modern utama baru muncul adalah setelah adanya ekspansi Eropa melintasi samudera yang dimulai pada abad ke-15 dan didorong oleh faktor-faktor berbeda. Oleh karenanya, bagi dunia Islam pengaruh Barat secara efektif bermula tahun 1498 ketika Vasco da Gama membuka jalan laut ke India melalui Tanjung Pengharaan dan berbagai bangsa Eropa mulai melakukan perniagaan dengan Afrika Timur, anak benua India, India Timur, dan Timur Jauh (Watt, 1997). Selanjutnya, Wahabi merespon kekuatan modernitas yang mengacaukan keseimbangan tersebut dengan mencari tempat perlindungan. Dalam hal ini, perlindungan itu diperoleh dengan melekatkan diri pada teks-teks keagamaan untuk mendapatkan kepastian dan rasa kenyamanan. Al-Quran dan sunnah dengan pemahamannya yang literal dianggap sebagai satu instruksi manual untuk menggapai keselamatan dan kejayaan.

Konsekuensinya, Wahabi menganggap bahwa berbagai bentuk pemikiran yang tidak secara keseluruhan bergantung pada teks sebagai satu bentuk pemujaan diri (self idolatory) dan meletakkan bidang-bidang ilmu pengetahuan, khususnya filsafat yang dianggap menyesatkan. Dengan menyeru untuk kembali kepada Islam yang murni, sederhana, dan lugas, ajaran Wahabi menolak berbagai usaha menginterpretasi hukum Allah dari sudut pandang sejarah dan perspektif kontekstual, karena semua itu merupakan sebuah korupsi terhadap Islam yang benar dan otentik. Dengan kata lain, proses intelektualisasi (diskusi) seperti yang dilakukan oleh kaum modernis bagi Wahabi menjadi tidak penting, karena yang penting bagi mereka adalah ketaatan mutlak pada Allah (iman); iman membuat orang mengerti, dan bukan mengerti yang membuat orang menjadi beriman (Mahendra, 1996, hal. 101).

Tradisi yurisprudensi klasik yang sangat baik dianggap Wahabi sebagai cara berpikir yang menyesatkan belaka. Mereka menjadi sangat tidak toleran terhadap berbagai praktik keagamaan yang sudah berlangsung lama dan menganggap berbagai 
macam madzhab pemikiran menjadi sama-sama ortodoks dengan pengertian yang sempit. Dampak lanjutan dari cara pandang seperti ini adalah Wahabi seringkali menciptakan daftar panjang tentang praktik-praktik keagamaan sebagai inovasi bid'ah dan orang-orang muslim kontekstual sebagai orang-orang kafir.

Pada abad ke-18 keluarga Sa'ud bergabung dengan gerakan Wahabi dan memberontak melawan pemerintahan Turki Usmani di Arabia. Aliansi antara keduanya sejak tahun 1745 hingga 1818 dikenal sebagai Negara Saudi pertama yang berakhir ketika militer Mesir dan Turki menghancurkan kota al-Dir'iyyah, ibu kota kerajaan Saudi pertama (Khalid M.Abou el, 2006). Pasukan Mesir menggagalkan pemberontakan ini pada tahun 1818, akan tetapi ideologi Wahabi kembali bangkit pada awal abad ke-20 di bawah kepemimpinan Abd al-Aziz bin Sa'ud (pendiri negara Saudi modern) yang bersekutu dengan suku-suku Najd, pada permulaan yang kemudian menjadi Saudi Arabia. Dalam hal ini, penting untuk diketahui bahwa ada berbagai tahap yang mengantarkan berdirinya kerajaan Saudi pada tahun 1932, yaitu; negara Saudi pertama yang gagal (1745-1818), negara kedua juga gagal kira-kira dari 1824-1891), baru yang ketiga, negara Saudi berhasil bertahan (dimulai pada tahun 1902 dan berlanjut hingga 1932) (Khalid M.Abou el, 2006). Keluarga al-Saud dan Wahabi ini telah meninggalkan jejak intoleransi, kebencian, dan fanatisme yang luar biasa yang berujung pada berbagai aksi kekerasan.

Dalam perkembangannya, dengan memperlakukakan pemerintahan Turki Usmani Muslim sebagai kekuatan yang asing yang menduduki Arab, maka Wahabisme menetapkan sebuah gagasan kuat tentang otonomi dan penentuan nasib sendiri bagi Arab. Di sinilah terlihat bahwa hubungan antara keluarga al-Sa'ud dengan Wahabi berlangsung dengan baik, lebih dari sekedar hubungan pragmatis dan saling memberi dukungan. Saudi dan Wahabi menemukan satu model untuk menjawab persoalan tentang bagaimana negara Islam seharusnya bertindak di dunia modern. Menurut model ini, yang kemudian berpengaruh di kalangan muslim puritan, kekuasaan intrusif negara yang baru sungguh-sungguh membatasi kebebasan individu dan memaksa orang yang menentang untuk menaati tata perilaku yang sangat spesifik -semua dilakukan dengan alasan untuk memperkuat hukum Allah. 
Lebih jauh, dalam model Saudi, negara mencipta dan memperkuat apa yang pada akhirnya disebut unit polisi agama (polisi Syariat) yang memainkan peran ganda: pertama, memaksakan ortodoksi kaku yang didukung negara, dan kedua, menghancurkan semua wujud keragaman agama dan perbedaan pendapat (Khalid M.Abou el, 2006). Perkembangan dan penyebaran pemikiran-pemikiran Wahabi mencapai tahap luar biasa adalah pada saat ditemukannya minyak di Arab Saudi. Pemanfaatan sumber daya minyak ini menjadi dana segar yang melimpah untuk negara itu. Lebih-lebih setelah tahun 1975, dengan naiknya harga minyak, Arab Saudi dengan agresif mendukung promosi pemikiran Wahabi ke seluruh dunia (Khalid M.Abou el, 2006).

Awalnya, proses penyebaran itu dilakukan dengan memberikan dukungan finansial pada organisasi-organisasi penting, namun pada tahun 1980-an, proses ini menjadi lebih canggih dan menyeluruh. Misalnya, Arab Saudi menciptakan organisasi perwakilan seperti Liga Muslim Dunia (Rabithah al-'Alam al-Islami), yang secara luas mendistribusikan literatur Wahabi dalam semua bahasa utama dunia, memberikan hadiah dan sumbangan serta menyediakan dana untuk jaringan penerbit, masjid, dan lembaga-lembaga pendidikan. Efek kampanye ini adalah banyak gerakan Islam di seluruh dunia menjadi pendukung ideologi Wahabi. Wahabisme tidak tersebar di dunia muslim modern di bawah benderanya sendiri. Wahabisme menyebar ke dunia muslim di bawah bendera Salafisme. Mengingat asal-usul Wahabi yang marginal, tentu penyebaran yang bersifat massif sulit dilaksanakan, berbeda jika penyebarannya menggunakan bendera Salafisme, karena Salafisme mempunyai otoritas dan kredibilitas tertentu di mata umat Islam secara umum.

\section{Asal-Usul Salafi}

Salafisme adalah suatu keyakinan yang didirikan pada akhir abad ke-19 oleh para reformis muslim seperti Jamaluddin al-Afghani (w. 1314 H/1897 M), Muh\}ammad Abduh (w. 132H/1905 M), Muhammad Rasyid Ridha (w. 1354 H/ 1935 M), Muhammad al-Syaukani (w. 1250 H/1834 M), dan Jalal al-Shan'ani (w. 1225 H/ 1810 M) (Khalid M.Abou el, 2006). Sejumlah orang bahkan menisbatkan asal-usul keyakinan salafisme 
ini kepada Ibnu Taimiyyah (w. 728 H/1328 M) dan muridnya yang bernama Ibnu Qayyim al-Jawziyyah (w. 751 H/ 1350 M).

Istilah salaf berarti pendahulu, dan dalam konteks Islam pendahulu itu merujuk pada periode Nabi saw, para sahabat, dan tabi'in. Selain itu, istilah salafi (seseorang yang mengikuti kaum salaf) punya makna fleksibel dan lentur serta memiliki daya tarik natural, sebab ia melambangkan autentisitas dan keabsahan. Dalam perkembangannya, sebagian ulama menambahkan kata as-salih di belakang kata al-salaf. Penambahan kata ini dimaksudkan untuk memberi karakter pembeda atas para pendahulu di luar ketiga periode yang biasa disebut al-khalaf (Idahram, 2013, hal. 25).

Sebagai istilah, salafi dimanfaatkan oleh setiap gerakan yang ingin mengklaim bahwa gerakan itu berakar pada autentisitas Islam. Walaupun istilah itu pada awalnya dipakai oleh kaum reformis liberal, pada awal abad ke-20, kaum Wahabi menyebut diri mereka sebagai kaum salafi. Akan tetapi hingga tahun 1970-an, istilah itu tidak terkait dengan keyakinan Wahabi (Khalid M.Abou el, 2006).

Spirit mendasar Salafisme awal adalah seruan kepada ajaran fundamental Islam, yaitu kewajiban umat Islam untuk taat dan tunduk kepada Nabi saw dan para sahabatnya. Generasi Nabi saw dan sahabatnya ini harus dijadikan role model oleh umat Islam dalam setiap gerak langkah kehidupannya. Sekali lagi, inilah spirit mendasar Salafisme awal yang 'berbeda' dengan Wahabi. Selanjutnya, Salafisme awal juga masih toleran terhadap kebhinekaan pendapat di kalangan umat Islam, berbeda dengan Wahabi yang sangat intoleran terhadap kebenaran plural. Atas dasar perbedaanperbedaan tersebut, Abu Zahrah (t.th.: 238) tidak menyebut Wahabi sama dengan Salafi, akan tetapi lebih menyebut kaum Wahabi memiliki kesamaan dengan kaum Khawarij yang mengkafirkan orang-orang yang berbeda pendapat dan memerangi mereka dengan kekuasaannya. Bahkan, mereka juga mirip dengan kelompok Mu’tazilah yang berkuasa pada masa Abbasiyah yang penyebarannya menggunakan alat politik dengan cara melakukan mihnah. Para pendiri Salafisme menekankan bahwa dalam berbagai persoalan, umat Islam harus kembali kepada al-Quran dan sunnah Nabi saw. Dalam melakukan ini, mereka cukup merujuk pada penafsiran-penafsiran generasi muslim awal yang tiga. 
Salafisme awal tidaklah intoleran terhadap kebhinekaan pendapat, yang berarti Salafisme tidak anti penalaran (intelektualitas). Hanya saja, mereka tidak begitu suka terhadap dinamika sejarah. Hal ini karena mereka sangat mengidealisasi masa Nabi saw dan para sahabatnya sebagai sebaik-baik masa (khairul qurun), sehingga dinamika sejarah setelahnya sekalipun juga memiliki warisan sejarah yang kaya dianggap tidak penting (kurang berharga). Sekalipun demikian, Salafisme tidaklah seekstrim Wahabi, ia masih sedikit toleran terhadap tradisi kebhinekaan dalam pemikiran hukum (mazhab). Berbeda dengan Wahabi yang menolak tradisi kebhinekaan mazhab dan bahkan cenderung menghilangkanya dari khazanah pemikiran hukum Islam. Dalam hal ini Wahabi berprinsip kebenaran itu tunggal bukan plural. Perbedaan lainnya, Salafisme dengan Wahabi adalah pada sikap keduanya terhadap westernisasi; Salafisme tidak sama sekali anti westernisasi, sementara Wahabi sangat anti dan menolak westernisasi.

Pola sikap Salafisme (yang berbeda dengan pola sikap Wahabi) adalah pola sikap Salafisme awal, atau pola sikap seperti ini bisa disebut sebagai pola sikap 'liberal' Salafisme. Pola sikap seperti ini berakhir pada tahun1960-an. Setelah itu, khususnya setelah tahun 1975 Wahabi mulai mengkooptasi Salafisme sehingga diidentik dengan satu paham yang tidak bisa dibedakan. Hal itu disebabkan adanya kesamaan visi untuk mengembalikan kejayaan Islam dalam konteks Islam kontemporer. Konsekuensinya ialah adanya penolakan terhadap kritik sejarah Islam dan memilih bersembunyi di balik teks-teks keagamaan setiap berhadapan dengan tantangan moderrnitas yang empiris. Setiap bentuk khazanah intelektual yang berwawasan moral rasional dianggap sebagai sesuatu yang bertentangan dengan Islam, karena dapat mengurangi kemurnian ajaran Islam. Sekalipun sikap semacam ini sebenarnya menunjukkan adanya sesuatu yang kontradiktif di dalamnya, sebab jika dicermati betapa peradaban Islam itu sendiri telah menghasilkan satu tradisi filsafat Islam yang sangat kaya (Khalid M.Abou el, 2006).

Pada fase inilah, kemudian Salafisme dan Wahabisme masuk ke fase apologetisnya. Keduanya sama-sama memiliki sejenis pemikiran yang memandang diri mereka sebagai kelompok superior dan lebih unggul (K. M. A. el- Fadl, 2003a, hal. 5758). Oleh karena merasa superior, maka mereka merespon tantangan-tantangan intelektual yang datang dari Barat dengan mengadopsi fiksi-fiksi kesalehan tentang tradisi Islam. Mereka mengelak penilaian kritis terhadap doktrin-doktrin Islam dan 
merayakan kesempurnaan Islam menurut apa yang mereka sangkakan. Dalam banyak hal, respon apologetik tersebut, secara fundamental mereka pusatkan pada kekuasaan (daulah). Tujuan utamanya bukan untuk menyatukan nilai-nilai partikular di dalam dunia Islam, tetapi untuk memperkuat Islam melawan musuh peradabannya. Akibat buruk dari sikap apologetis ini adalah menyumbangkan rasa 'intelektual kecukupan diri' yang seringkali merosot pada arogansi moral, namun mereka tidak menyadarinya. Pemikiran semacam ini terus bertahan hingga kini. Dalam konteks ini, karya-karya yang lahir dari kaum Salafi generasi awal seperti Muhammad Abduh dan Rasyid Ridha yang memperlihatkan tingkat kecanggihan intelektual mereka, menjadi jarang (untuk enggan mengatakan tidak) ditemukan. Karya-karya kaum Salafi menjadi tidak bisa dibedakan dengan Wahabi (Khalid M.Abou el, 2006). Perpaduan Salafisme dan Wahabisme yang mulai terjalin pada tahun 1970-an inilah yang membentuk teologi gerakan puritan saat ini.

\section{Metode Penelitian}

Artikel ini menggunakan metode penelitian kualitatif dengan pendekatan induktif yang mencoba untuk menyusun pemikiran seorang dengan analisis deskriptif (Azwar, 2010, hal. 13) yang bertujuan untuk memberikan gambaran dari objek yang bersifat khusus, sehingga dapat ditarik pada simpulan umum. Penelitian ini bersifat kepustakaan (Library Research) pengumpulan data dilakukan melalui tulisan, gambar atau karya seseorang yang mempunyai relevansi (Sugiyono, 2005). Sehingga dapat mengambil simpulan dari data-data yang telah dianalisa.

\section{Membaca yang Otoritatif, Otoritas dan Otoriter}

Merujuk pada tulisan Muhtador tentang otoritas menjelaskan bahwa, setidaknya terdapat empat hal yang dapat dijadikan sumber otoritas. Wahyu, hasil pembuktian empiris, kekuatan penalaran manusia, dan tradisi yang telah mapan (Muhtador, 2012). Dalam hal ini wahyu dipahami sebagai petunjuk Allah yang diturunkan hanya kepada Nabi. Dalam dogma Islam wahyu menepati urutan pertama sebagai sumber otoritas yang sejatinya adalah otoritatif, karena ajaran agama disampaikan melalui wahyu. Meskipun wahyu sudah terbentuk al-Quran dan kitab undang-undang yang lengkap, 
tetapi al-Quran memuat pernyataan-pernyataan legal, yang menjadi petunjuk moral umum, sehingga menjadi tindakan seorang muslim (Esposito, 2004, hal. 99).

Selain wahyu, pengalaman empirik juga menjadi rujukan otoritas dalam kehidupa, seperti kemajuan teknologi. Pembuktian empirik pernah dilakukan dalam mengkaji hadis Nabi, seperti hadis yang menyatakan bahwa "sembilan malaikat terusmenerus melempari bola salju kematahari pada malam hari”. Hadis ini harus dilakukan dengan observasi ke sistem galaksi untuk menemukan kebenarannya, karena kajian empirik tidak bersifat spekulatif. Dalam bukunya Hasyim Abbas menjelaskan bahwa tidak ditemukan gambaran frekuensi lemparan bola salju. Dalam kajian fisika mensinyalir bahwa yang menimalisir bahaya radiasi dari panas matahari adalah faktor jarak dengan planet bumi (Abbas, 2004, hal. 122). Pada wilayah yang sama, nalar juga memainkan perannya sebagai sumber otoritas. Kasus tentang penafsiran dan pemahaman atas teks yang tidak ditemukan dalam sumber otoritatif adalah bentuk usaha nalar, seperti usaha khalifah, qadhi, dan fuqaha atau serjana hukum ketika membuat hukum dan tidak menemukan teks yang jelas secara eksplisit yang diwahyukan dan tidak terdapat ijma, logika memainkan perannya dalam menafsirakan dan mengkonstruk pemikiran untuk dijadikan produk hukum. Tradisi yang mapan atau juga disebut ijma, menjadi sumber otoritas, dalam Islam sering disandarkan pada pernyataan nabi "umatku tidak akan bersepakat dalam kesesatan". Tradisi belum berkembang sebagai suatu hukum sampai wafatnya Nabi. Peran penting yang dimiliki tradisi dalam hukum Islam dan memberikan sumbangan yang sangat signifikan bagai kemajuan hukum atau tafsir hukum. Jika pertanyaan-pertanyaan muncul terkait dengan makna suatu teks al-Quran atau sunah, atau jika wahyu dan praktik muslim awal tidak menyatakan sesuatu, maka para fuqaha menggunakan ijtihad (penalaran pribadi) mereka untuk menafsirkan hukum. Dalam dogma agama, wahyu yang sudah termanifestasikan dalam bentuk teks al-Quran maupun hadis adalah sumber otoritatif yang harus diutamakan, dari pada yang lainnya.

Selain wahyu bagian terkecil dari sumber otoritatif yang biasa digunakan oleh kelompok interpretatif yang disebut otoritas. Adapun otoritas dikonstruk dari berbagai gejala yang dialami oleh kelompok interpretasi. Dalam Islam. Allah adalah pemegang kedaulatan. Tetapi kedaulatan ini hanya bisa dijalani melalui agen-agen manusia. Agen 
manusia dengan penuh keyakinan melaksanakan kehendak Allah melalui seperangkat instruksi tertulis yang diturunkan kepada Nabi Muhamma, tetapi wahyu hanya berakhir bersamaan dengan wafatnya Nabi, sehingga teks-teks agama membutuhkan agen untuk menafsirkannya (K. A. El Fadl, 2001, hal. 46). Pada beberapa kesempatan, al-Quran merujuk pada fakta bahwa Allah telah menciptakan manusia sebagai khalifah di muka bumi, khalifah bisa berarti pewaris, agen atau pelaksana, tetapi gagasan dasarnya adalah bahwa manusia diciptakan sebagai agen Allah di muka bumi. Sebagai agen Allah manusia menjadi juru bicara dalam menyampaikan pesan Allah yang termanifestasikan dalam teks (Khaled, 2003) .

Al-Quran dan hadis mempunyai posisi seperti Allah, karena bagian dari representasi wahyu. Tetapi untuk mengaplikasikan keduanya membutuhkan agen atau kelompok interperatasi, pada posisi ini manusia menjadi agen interpretasi dan mempunyai otoritas dalam beragama. Dengan bahasa sederhana, keberwenangan Allah selalu diwakili dan dinegosiasikan oleh manusia, dan al-Quran sendiri telah mengisyaratkan bahwa manusia diciptakan sebagai wakil Allah. Namun wakil Allah dibagi menjadi dua yaitu wakil umum dan wakil khusus. Wakil umum memandang bahwa wakil khusus memiliki otoritas atas kompetensi dan pemahaman terhadap perintah Allah (Khaled, 2003).

Ada beberapa alternatif metodologis yang bisa digunakan untuk menganalisis persoalan otoritas dalam agama dari sudut pandang rasional yang bersifat normatif. Dengan kata lain, sehingga dapat melihat otoritas Allah dan manusia dan keterkaitan keduanya dari perspektif yang murni bersifat rasional dan filosofis. Hal itu bahkan dapat menyatakan bahwa dari sudut pandang normatif, nilai-nilai yang menjadi faktor penentu, seperti rasionalitas, keadilan, kesejahteraan, dan nilai-nilai pokok lainnya, merupakan standar otoritatif yang harus menjadi rasa untuk membangun gagasan tentang otoritas dalam Islam, seperti seorang dapat menegaskan bahwa keadilan merupakan nilai kunci yang sangat menentukan dan kemudian melakukan pengujian apakan al-Quran mampu atau menjujung tinggi atau paling memenuhi nilai-nilai pokok tersebut. Apabila hal tersebut tidak mewakili, kita dapat menyimpulkan bahwa al-Quran tidak bersifat otoritatif atau tidak bisa dijadikan sumber otoritas. Tetapi al-Quran kitab 
yang sudah memuat nilai-nilai tersebut secara universal, sehingga kandungan dapat diaplikasikan pada kehiduapn sehari-hari.

Alternatif lainnya adalah memilih pendekatan hermeneutik, seperti dapat mengambill teks keagamaan semata sebagai sebuah teks, menentukan apa yang terpandang sebagai penentuan makna-penulis, teks, pembaca, atau ketiganya-dan terus diteliti teori-teori yang berkaitan dengan ketiga unsur tersebut dengan teori hermeneutika, karena masing-masing unsur mempunyai konteksnya sendiri. Dengan melakukan pendekatan ini, akan mendasarkan argumentasi pada keterkaitan ketiga unsur itu dalam teks keagamaan-atau melepaskan bagian-baigan yang ada pada unsur tersebut-dan meneruskan pembacaan ketiga unsur itu dalam teks keagamaan untuk mencari sebuah konsep tentang otoritas (Khaled, 2003).

Problematika yang akan muncul atas kajian penafsiran ialah sikap pembaca atas teks itu sendiri yang dapat mencederai teks agama, seperti sikap otoriter atau stagnasi pemikiran, karena berdampak pada tafsir otoriter (Muhtador, 2012). Dalam pandangan Abou Fadl, persoalan otoritarianisme kurang mendapatkan tempat bagai sarjana muslim, penetapan makna terkait erat dengan sikap dan kejujuran penafsir. Epsitemologi otoritarianisme berawal dari ketidakjujuran sikap, yang menyebabkan tafsir otoriter. Bagai sarjana muslim sikap demikian disejajarkan dengan tafsir spekulatif, padahal hal tersebut mempunyai dampak negatif yang dapat mengancam keterbukaan dalam beragama yang menyebabkan penolakan atas produk pemahaman yang lain. Bagai sebagaian orang muslim penolakan terhadap kemungkinan interpretasi yang melibatkan pengaruh dari unsur-unsur luar dan kegigihan mempertahankan intrepretasi yang tidak memasukkan unsur dari luar dipandang sebagai bentuk otokrasi atau despotism (Khaled, 2003).

Dalam kajian teks, pembaca menafsirkan teks dengan mengkonstruksi maknanya. Kontruksi makna yang dibuat oleh pembaca boleh jadi sesuai dengan makna yang dimaksud oleh pengarang teks, tetapi bisa juga tidak. Dalam kenyataannya, selalu ada ketegangan antara pembaca dan teks, seperti kasus ketika seorang ingin memahami ayat "La Ikraha Fi Al-Din". Ayat ini bisa mempunyai makna tidak boleh memaksa siapapun untuk masuk agama Islam atau seseorang mungkin saja dipaksa untuk 
menjadi seorang muslim, tetapi tidak akan bisa dipaksa untuk meyakini Islam, dan beberapa arti yang masih mungkin bisa dikonstruksi. Pembaca mengkonstruksi makna teks dalam memahami ayat tersebut dengan mendekati dan membacanya. Teks hanya menyatakan tidak ada paksaan dalam agama. Kemungkian-kemungkian akan muncul dari penafsir seperti paksaan dalam shalat, hijab, dan perjanjian, tetapi bisa juga tidak.

Pembaca mendekati teks yang bersifat otoritatif yang bersumber dari wahyu untuk memahami dan menafsirkan sebagai usaha menggali makna teks. Apabila pembaca mengutip teks dan kemudian menyatakan suatu interpretasi dan dijadikan sebagai legitimasi tindakan, pembaca telah menyatukan dirinya dengan teks. Pada wilayah ini pembaca harus berhati-hati karena akan mengalami pertaruhan identitas tafsir, karena pemahaman yang diproduksi akan terjebak pada sikap otoriter ketika penafsir menyatakan kebenaran mutlak. Dengan demikian, penafsir akan menutup setiap pemahaman yang berbeda dari pemahaman sendiri, karean teks dan kontsruk yang diberi pembaca menjadi tunggal dan sama. Meskipun teks agama bersifat otoritatif tetapi pembaca berubah menjadi otoriter, karena kebenaran hanya disajikan melalui satu paham yang telah dipilih oleh pembaca, yang menolak atau tidak mengakui pembaca lain. Secara tidak sadar, pembaca telah mengklaim menjadi bagian dari teks dan teks dibuat tunduk kepada pembaca, dan akibatnya, pembaca menjadi pengganti dari teks. Pembaca tidak hanya telah berusaha mengkonstruksi makna teks, tetapi juga telah mengkonstruksi teks itu sendiri (K. A. El Fadl, 2001).

Pengambilan hak dalam mengkonstruksi teks lain (tafsir otoriter) adalah bagian dari kejahatan otoritarianisme yang menjadikan teks (tafsir teks) sebagai alat legitimasi ketika membaca teks secara otoriter. Pada posisi ini teks tidak lagi mampu berbicara dan telah dibungkam suaranya oleh pembaca dengan tafsir tunggal, dan bagaimanapun teks sudah membeku dalam kondisi terakhir dan diklaim pembaca secara menyeluruh. Oleh karena itu, teks pertama menjadi tertutup maknanya oleh pembaca karena pembaca telah menentukan maknanya dan dianggap final. Penutupan makna teks ini terjadi ketika pembaca bersikeras menentukan makna teks yang stabil, tetap, stagnan, dan tidak berubah, seperti kasus ketika makna dari dogma agama (al-Quran dan hadis) tertentu menjadi mapan dan diklaim menjadi tafsir tunggal, dengan sendirinya tafsir dari dogma tersebut telah dinyatakan tertutup. Konsekuensi logis dari peraktek tersebut ialah 
penutupan dogma agama yang menjadikan ajaran agama dipandang tidak lagi relevan untuk masa yang akan datang. Penetapan makna terakhir yang diletakkan pada teks akan menyegel makna dogma agama untuk selamanya (Khaled, 2003). Dalam pandangan Abou el Fadl, kasus tentang penutupan makna pernah dilakukan oleh kelompok fatwa di Arab Saudi, instansi ini menegaskan bahwa seorang istri harus taat dan tunduk pada suaminya dengan mengutip berbagai hadis yang keluar dari kontek ketaatan dan ketundukan kepada suami. Hadis-hadis semacam itu menyebutkan bahwa derajat kesalehan seorang istri bergantung pada keridhaan suaminya. Misalnya hadis yang menyatakan, bahwa Nabi pernah bersabdah, "salat dan perbuatan baik seorang isteri tidak akan diterima Tuhan selama suaminya masih marah kepadanya" (K. A. El Fadl, 2001).

Dalam pergerakan sosok yang otoriter, perbedaan antara wakil Tuhan dan sebagai Tuhan menjadi tidak jelas dan kabur. Pernyataan seorang wakil dan kehendak Tuhan menjadi satu dan serupa, Karena seorang wakil mencangkokan penetapannya ke dalam perintah Tuhannya. Karena Tuhannya diwakili oleh petunjuk-petunjuk tekstual dan nontekstual, dalam sebuah proses yang otoriter, seorang wakil, untuk kepentingan praktis, menafikan otoritas petunjuk-petunjuk tersebut dan menjadikan bunyi isyarat tersebut sepenuhnya bergantung pada penetapannya sendiri. Dinamika sosok yang otoriter menolak integritas petunjuk teks dengan menutup kemungkinan bagi petunjuk-petunjuk tersebut untuk mengungkap dirinya sendiri, dan menghalangi perkembangan evolusi makna komunitas interpetasi (Khaled, 2003).

\section{Kaum Moderat dan Tantangan Puritanisme}

Paparan tentang ikatan teologis antara Salafisme dan Wahabisme menghasilkan sikap apologetis, maka buah selanjutnya dari perpaduan itu adalah rasa keterasingan yang akut, baik dari institusi-institusi kekuasaan dunia modern, bahkan juga dari warisan dan tradisi Islam sendiri. Dalam konteks kekinian, puritanisme tidak lagi direpresentasikan oleh institusi-institusi formal, melainkan puritanisme telah menjadi orientasi teologis (world view).

Ada banyak variasi dan kecenderungan ideologis puritanisme, namun demikian ciri khas yang menjadi identitasnya adalah konsisten pada ideologi supremasi; bahwa 
mereka selalu merasa lebih unggul dan superior, yang berfungsi sebagai kompensasi atas perasaan kalah, tidak berdaya, dan keterasingan, disertai sikap arogansi diri yang di dalamnya terkandung perasaan selalu benar ketika berhadapan dengan yang lain. Sementara kelompok di luar mereka, juga susah untuk diklasifikasikan apakah Barat (kaum ateis secara umum), atau bahkan kaum muslim sendiri yang dinilai melakukan bid'ah. Dengan melakukan pemetaan, akan mudah untuk mengidentifikasi kelompok lain yang biasa disebut sebagai kaum moderat. Sederhananya, jika kaum puritan identik dengan ideologi supremasi, maka kaum moderat adalah identik dengan ideologi moderasi. Muslim moderat merespon secara serius perintah-perintah al-Quran dan pernyataan-pernyataan Nabi saw yang menerangkan bahwa keseimbangan dan moderasi adalah inti semua kebaikan dan inti setiap kebajikan (Khalid M.Abou el, 2006). Menurut Aboul Fadl kaum moderat adalah mereka yang meyakini Islam, menghormati kewajiban-kewajiban kepada Allah (mengamalkan rukun Islam yang lima), dan meyakini bahwa Islam sangat relevan untuk segala zaman, mereka tidak memperlakukan agama mereka laksana monumen yang beku, tetapi memperlakukannya dalam kerangka iman yang dinamis dan aktif (Khalid M.Abou el, 2006); menerima warisan tradisi Islam, namun sekaligus memodifikasi aspek-aspek tertentu darinya demi mewujudkan tujuan-tujuan moral dari keyakinan itu di era modern.

Mencermati keberadaan kaum puritan, secara sederhana dapat dikatakan bahwa mereka adalah anak yatim modernitas. Mereka dilahirkan oleh serangan modernitas yang bertubi-tubi, tetapi seperti anak haram, mereka adalah aib bagi abad modern yang melahirkan mereka. Dengan kata lain, sikap puritan adalah hasil yang tumbuh dari ketegangan-ketegangan antara pandangan-dunia modernitas budaya dengan pandangan-dunia kosmologis monoteisme Islam (Tibi, 2000). Sedangkan mengenai sebab-sebab tumbuhnya gerakan Islam militan (baca: puritan), dapat juga dilihat pada buku karya S. Yunanta, Gerakan Militan Islam di Indonesia dan di Asia Tenggara (Yunanta, n.d., hal. 17-21).

Sepanjang waktu yang telah berlalu, semua sistem agama pernah terjangkiti ekstrimisme absolut, tidak terkecuali Islam. Akan tetapi, arus utama kaum muslim selalu berhasil mendominasi dengan memaksa kaum ekstremis ini untuk 
memoderatkan pandangan mereka. Selain Khawarij, ada ekstremis lain seperti Qaramitah dan Hasyasyin yang bisa menjadi rujukan. Sesudah berabad-abad terlibat dalam pertumpaan darah, dua kelompok ini mendapatkan penilaian yang sangat buruk dalam tulisan para sejarawan, teolog, dan ahli hukum Islam, namun dari situ mereka kemudian belajar bersikap moderat.

Poin penting yang bisa digarisbawahi bahwa kelompok ektremis tertolak dari arus besar Islam, atau dengan kata lain, ia tidak memiliki akar kuat dalam peradaban Islam. Mereka terpinggirkan, dan pada gilirannya mereka diperlakukan sebagai satu penyimpangan (bid'ah) dari ajaran Islam. Kondisi saat ini berbeda dengan kondisi kesejarahan sebelumnya. Jika pada waktu itu institusi-institusi tradisional yang bertindak dan berfungsi untuk memfilter keyakinan mereka masih ada, saat ini institusiinstitusi itu sudah tidak ada lagi. Inilah yang menyebabkan periode sejarah Islam sangat jauh lebih menyusahkan daripada sebelumnya, dan ini pula yang menjadikan orientasi puritan modern jauh lebih mengancam kepaduan moralitas dan nillai-nilai Islam daripada gerakan ektremis yang dahulu pernah ada.

Menurut Khalid Abou el-Fadl, salah satu penyebab utama dari kegagalan umat Islam dalam menghadapi puritanisme adalah keengganan para sarjana dan intelektual muslim untuk menunjukan bahwa Wahabi adalah pangkal dari gerakan puritan ini (Khalid M.Abou el, 2006). Khususnya pada tahun 1980-an, selain kalangan sufi dan Syi'ah, sangat sedikit sarjana yang berani mengkritisi pengaruh Wahabi pada paham Salafi. Kritik yang diarahkan pada Arab Saudi atau Wahabisme dipandang beresiko dan bahkan berbahaya. Setidaknya, melalui kendali mereka atas dua tempat suci, Makkah dan Madinah, pemerintah Saudi memiliki kekuasaan yang sangat kuat, yakni kekuasaan untuk memberikan visa atu tidak kepada setiap muslim di dunia. Kekuasaan untuk mengaatur akses ke Makkah dan Madinah ini pada akhirnya berarti bahwa pemerintah Saudi bisa memutuskan apakah seorang muslim akan dapat melaksanakan ibadah ke tempat suci itu atau tidak. Fakta ini saja memungkinkan pemerintah Saudi untuk memiliki peran yang berdampak sangat serius atas kehidupan umat Islam di dunia. Setiap sarjana muslim yang berani mengkritisi Wahabisme, umpamanya, tidak akan mendapatkan visa untuk mengunjungi tempat suci itu, dan bagi banyak kaum muslim yang saleh ini akan menjadi tamparan emosional yang sangat serius. 
Pada akhir tahun 1970-an dan awal 1980-an, Arab Saudi telah memulai kampanye sistematis untuk menyebarkan pemikiran Wahabi di kalangan umat Islam yang berada di negara-negara muslim maupun non muslim. Lebih penting lagi, Arab Saudi telah menciptakan sejumlah sistem bantuan finansial berskala dunia dengan memberi bantuan yang melimpah bagi mereka yang menyokong atau menahan diri mengkritisi paham Wahabi.

Menghadapi tantangan puritanisme, penulis setuju dengan gagasan Hasan Hanafi sebagaimana yang dikutip oleh (Nurhakim, n.d.), yaitu mengalihkan sikap-sikap konservatisme dan sikap cenderung menekankan simbol-simbol keagamaan kepada halhal yang lebih substantif. Hal ini dapat dilakukan dengan melibatkan mereka di dalam berbagai kegiatan dialog antar iman, terbuka atau tertutup. Dalam bahasa Habermas sebagaimana yang dikutip oleh (Sindhunata, 2004, hal. 60), disebut dengan tindakan komunikatif yaitu tindakan komunikasi yang tidak berangkat dari situasi monologis (di mana ada saya dan kamu), tetapi dari situasi dialogis (yang ada adalah kita).

Menurut hemat penulis, kegiatan seperti ini tidak kalah pentingnya dibanding dialog antar agama. Karena, sebagaimana telah maklum bahwa kekerasan sektarian dewasa ini, terjadi bukan hanya di antara pemeluk agama yang berbeda, tetapi juga di antara pemeluk agama yang sama, bahkan intoleransi (kekerasan) antara pemeluk agama yang sama cenderung lebih sulit dicarikan resolusi konfliknya, seperti kekerasan Syiah terhadap Sunni ataupun sebaliknya, dan juga kekerasan Sunni terhadap Ahmadiyah.

\section{Kedudukan Perempuan Dalam Kaca Mata Puritan dan Moderat}

Sub judul ini adalah satu kasus (case) yang sengaja diangkat oleh penulis untuk memaparkan secara lebih kongkrit mengenai dampak dari perbedaan cara pandang Islam puritan dan Islam moderat terhadap isu-isu aktual dewasa ini, seperti kedudukan perempuan. Pada dasarnya, spirit yang diusung Islam puritan adalah kembali kepada alQuran dan Sunnah (al-ruju' ila al-Quran wa al-Sunnah), namun dengan beberapa karakter menonjol yang ada di dalamnya seperti; oppositionalism (paham perlawanan), penolakan terhadap hermeneutika, penolakan terhadap pluralisme dan relativisme, dan penolakan terhadap perkembangan historis dan sosiologis (Ilyas, 2004, hal. 26-27), 
maka cara mereka kembali kepada al-Quran dan Sunnah menjadi sangat tekstualisliteralis tanpa mempertanyakan lebih lanjut mengapa suatu nash berbunyi seperti itu (bila kaifa bi ghairi takyif). Dengan kata lain, paradigma keislaman yang dibangun adalah tathbiq as-Syari'ah yaitu model paradigma keislaman dengan cara menekankan pentingnya kembali kepada penerapan Syari'ah Islam (Abdullah, 2016)(Abdullah, 2003, hal. 24).

Adapun landasan epistemologi pemikiran ini adalah berangkat dari keyakinan adanya suatu konsep abadi yang merupakan petunjuk Allah Swt kepada para hambaNya. Petunjuk ini dipahami sebagai perintah dan larangan abadi, mengatasi sejarah dan terbebas dari campur tangan manusia dan pembentukannya. Itu merupakan kehendak Allah atas hamba yang terkandung dalam firman-Nya yang diturunkan secara verbal melalui skenario yang sudah dibuat dari zaman azali. Sikap yang benar dari manusia terhadap-Nya hanyalah patuh dan taat, tanpa mempertanyakan mengenai keabsahannya (Machasin, 2005, hal. 20). Dengan kata lain, teks-teks keagamaan ditujukan untuk mengatur segala aspek kehidupan dan karenanya tidak mungkin bagi logika dan estetika (kemampuan bawaan manusia) untuk mampu berpikir secara cermat dan mengetahui sesuatu yang baik.

Salah satu hal menonjol sebagai akibat dari paradigma keislaman adalah pemahaman orang-orang puritan terhadap perempuan. Dalam hal ini, ada satu kata yang merangkum sikap puritan terhadap perempuan yaitu 'fitnah'. Fitnah adalah sebuah istilah umum yang memiliki banyak arti, yang kesemuanya negatif. Fitnah berarti godaan seksual, sumber bahaya, kerusakan social, kekacauan, dan kejahatan yang akan datang. Walaupun, orang-orang puritan acap kali memuji dan mengakui peran perempuan sebagai ibu, akan tetapi dalam peran-peran lain perempuan dipotret sebagai tidak sempurna. Karena itulah, sebagai seorang istri, ia sepenuhnya berada di bawah pengawasan suaminya. Sebagai anak, ia berada di bawah pengawasan ayahnya. Sebagai anggota masyarakat, ia berada di bawah pengawasan semua laki-laki. Ia tidak pernah menjadi manusia yang independen dan otonom yang memiliki kewajiban setara dalam memenuhi pertjanjian Allah. Singkatnya, dalam paradigma puritan, perempuan diproyeksikan mengambil peran dengan memenuhi kewajibannya hanya melalui lakilaki (sebagai suami, ayah, ataupun laki-laki yang mengontrol ruang publik). 
Pandangan tentang perempuan sebagai fitnah dalam praktiknya banyak didasarkan pada hadis-hadis yang secara redaksional terkesan merendahkan kaum perempuan (misoginis). Hadis-hadis tersebut adalah hadis tentang penghuni neraka kebanyakan perempuan dan kodrat perempuan kurang akal dan kurang agama (AlKirmani, 1991, hal. 6), hadis tentang perempuan, keledai, dan anjing hitam dapat membatalkan shalatnya laki-laki (Al-Utsmain, n.d., hal. 363), hadis tentang perempuan dicipta dari tulang rusuk laki-laki (Nawawi, 1972, hal. 57-58) dan lain-lain.

Orang-orang puritan dengan paradigma tathbiq as-Syari'ah menempatkan hadis-hadis tentang misoginis sebagai bersifat normatif bukan bersifat empiris (K. M. A. el- Fadl, 2003b, hal. 351), dan karenanya apa yang terbaca dalam hadis-hadis tersebut harus dipahami begitu saja apa adanya tanpa mempertimbangkan lebih jauh kondisi dan situasi sejarah serta perkembangan cara berpikir dan kebudayaan manusia itu sendiri. Berbeda dengan puritan, kaum moderat tidak menggunakan tathbiq asSyari'ah sebagai paradigma keislamannya, melainkan tajdid al-fahmi, yaitu sebuah paradigma keislaman yang lebih menekankan pada metode berpikir (the way of thinking).

Adapun landasan epistemologi pemikiran ini adalah berangkat dari keyakinan bahwa agama Islam adalah sebuah tradisi kemanusiaan yang terbentuk melalui proses sejarah proses manusia dalam pergulatannya dengan persoalan zamannya. Ini terlihat jelas dalam sejarah Nabi Muhammad saw sendiri yang sadar akan keruntuhan moral dan sistem sosial masyarakatnya, berusaha untuk mencari pemecahan persoalan zamannya dengan menyepi di gua-gua sekeliling Makkah. Dengan demikian, khazanah tradisi dan tarikh Islam mesti dilihat sebagai khazanah dan tarikh manusiawi yang jauh dari kekudusan.

Dalam praktiknya, biasanya kaum moderat lebih fokus pada penafsiran Islam substansial-kontekstual sesuai dengan denyut nadi peradaban manusia yang sedang terus berubah. Dengan kata lain, penafsiran Islam yang dikembangkan adalah penafsiran Islam yang memisahkan mana unsur-unsur Islam yang merupakan kreasi budaya (pengaruh kultur Arab) dan mana yang merupakan nilai-nilai fundamental. Islam itu kontekstual, nilai-nilainya yang universal harus diterjemahkan dalam konteks 
tertentu, misalnya konteks arab, Melayu, Asia Tenggara, dan seterusnya, tetapi bentukbentuk Islam yang kontekstual itu hanya ekspresi budaya dan tidak wajib diikuti. Dalam hal ini, aspek-aspek Islam yang merupakan cerminan kebudayaan Arab, misalnya soal jilbab dan potong tangan tidak wajib diikuti karena meruipakan ekspresi lokalpartikular Islam di Arab (Mudzhar, 2002, hal. 19).

Dari sini, kaum moderat mencermati bahwa salah satu nawacita yang termanifestasikan di dalam nilai-nilai fundamental tersebut adalah kesetaraan di antara sesama manusia. Di hadapan Allah, perempuan itu setara dengan laki-laki karena diganjar dan dihukum dengan takaran serupa, dan mereka juga memiliki akses yang sama kepada anugerah dan kebaikan Allah. Dari sini, hadis-hadis yang terkesan merendahkan perempuan (hadis-hadis misoginis) sebagaimana disebutkan di atas tidak dipahami sebagai seratus persen normatif tetapi juga dilihat aspek historis dan empirisnya.

Dalam pandangan Abou Fadl, untuk melepaskan diri dari sikap otoriter atau dari kemunculan paham otoritarianisme seorang harus mempunyai metodologis yang komprehensif. Dalam hal ini, Abou Fadl mengajukan lima syarat keberwenangan yang harus dipenuhi mufasir dalam menginterpretasikan dogma agama, supaya penafsir tidak menyelewengkan otoritas, yaitu kejujuran, kesungguhan, komprehensif, rasionalitas dan pengendalian diri. Dalam pandanga Muhtador (Muhtador, 2012) bisa disebut sebagai prinsip-prinsip penafsiran, karena tidak hanya berbicara tentang penjagaan otoritas, tetapi juga menggagas bagaimana proses interpretasi menjadi bertanggung jawab.

\section{Simpulan}

Melalui kajian ini diketahui bahwa asal muasal Islam puritan dan Islam moderat adalah berakar pada pemikiran yang sama. Keduanya sama-sama berangkat dari kegelisahan untuk melakukan perubahan, hanya bedanya; jika Islam moderat melakukan perubahan dengan menatap ke depan sambil membawa masa lalu yang relevan, sementara Islam puritan sepenuhnya kembali ke masa lalu (masa as-salaf ashshalih Nabi saw, sahabat, dan tabi'in). Dari sini, kemudian Islam puritan menjadi tidak peduli pada 'Islam yang hidup' di masa kini maupun Islam yang pernah ada dalam 
sejarah di luar as-salaf ash-shalih. Mereka justru lebih mengidealisasi Islam yang dibayangkan, baik sebagai mitologi masa silam maupun sebagai utopia masa yang akan datang.

Barangkali semua sepakat bahwa mayoritas umat Islam pada dasarnya mentoleran puritanisme, tetapi tidak untuk kekerasan. Di sinilah pentingnya menyuarakan kembali tradisi moral Islam yang telah 'dicuri' oleh muslim puritan dengan kekerasan-kekerasan atas nama Allah yang dilakukannya selama ini, khususnya terhadap perempuan. Islam dan umat Islam mesti menjadi sarana perwujudan rahmat dan kasih sayang Allah bagi semua manusia. Kasih sayang dan moderasi yang menjadi nilai dasar Islam harus dibiakkan dalam hati sanubari setiap muslim, sehingga puritanisme ekstremis tidak mempunyai tempat lagi, sehingga pandangan-pandangan radikalis-apologetis terhadap isu-isu aktual seperti isu kedudukan perempuan dapat diredam atau bahkan dimoderasi. 


\section{Referensi}

Abbas, H. (2004). Kritik Matan Hadis, Versi Muhaddisin dan Fuqaha. Yogyakarta: Teras.

Abdullah, A. (2003). Pendekatan Hermeneutika dalam Studi Fatwa-fatwa Keagamaan. In Atas Nama Tuhan. Jakarta: Serambi.

Abdullah, A. (2016). Harmonisasi Hubungan antar Umat Beragama: Peran Tokoh Agama dan Politik dalam Membangun Kerukunan Umat Beragama. Harmonisasi Umat Beragama. Kudus.

Al-Kirmani. (1991). Al-Kirmani Syarh Sahih Al-Bukhari. Beirut: Dar Ihya' Al-Turas AlArabi.

Al-Utsmain. (n.d.). Fatawa Al-Syaikh.

Azwar, S. (2010). Metode Penelitian. Yogyakarta: Pustaka Pelajar.

El Fadl, K. A. (2001). Melawan Tentara Tuhan. Jakarta: Serambi.

Esposito, J. L. (2004). Islam Warna-Warni. Jakarta: Paramadina.

Fadl, K. M. A. el-. (2003a). The Ugly Modern and The Modern Agly: Reclaime The Beautiful in Islam. Gender and Pluralism.

Fadl, K. M. A. el-. (2003b). Tuhan dari Fikih Otoriter ke FIkih Otoritatif. (L. Yasin, Ed.). Jakarta: Serambi Ilmu Semesta.

Idahram, S. (2013). Sejarah Berdarah. Jakarta: LKis.

Ilyas, H. (2004). Akar Fundamentalis dalam Perspektif Tafsir AL-Quran. In A. M. Abegebriel \& A. Y. A. Abeveiro (Ed.), Negara Tuhan The Thematic Encyclopdeia. Yogyakarta: Multi Karya Grafika.

Izutsu, T. (2004). God and Man in the Qur'an: Semantic of teh Qur'an Wltanschauung. Kuala Lumpur: Islamic Book Trust.

Khaled, A. E. F. (2003). Atas Nama Tuhan. Jakarta: Serambi.

Khalid M.Abou el, F. (2006). Selamatkan Islam dari Muslim Puritan. (H. Mustafa, Ed.). Jakarta: Serambi Ilmu Semesta. 
Mahendra, Y. I. (1996). Fundamentalisme, Faktor dan Mada depannya. In Rekonstruksi dan Renungan Religius Islam. Jakarta: Paramadina.

Mudzhar, A. (2002). Pendekatan Studi Islam (dalam Teori dan Praktek). Yogyakarta: Pustaka Pelajar.

Muhtador, M. (2012). OtoritasTeks Sunah dan Problem Otoritarianisme (Sudi Pemikiran Khaled M. Abou El-Fadl). STAIN Kudus.

Najib, A. M. (2009). Gerakan Wahabi: Ajaran dan Metode Penyebaran. In Gerakan Wahabi di Indonesia. Yogyakarta: Nawasewa Press.

Nawawi, A. (1972). Sahih Muslim Bi Syarh Al-Nawawi. Beriut: Dar Al-Fikr.

Nurhakim, M. (n.d.). Islam Tradisi dan Reformasi. Bayumedia Publishing.

Rahman, F. (2000). Gelombang Perubahan dalam Islam: Studi tentang Fundamentalisme Islam. Jakarta: Rajawali Press.

Sindhunata. (2004). Berfilsafat di Tengah Zaman Merebak Teror. Basis, (11-12).

Sugiyono. (2005). Memahami Penelitian Kualitatif. Bandung: Alfath Offset.

Tibi, B. (2000). Ancaman Fundamentalisme. Yogyakarta: Tiara Wacana.

Watt, W. M. (1997). Fundamentalisme Islam dan Modernitas. Jakarta: Raja Grafindo Persada.

Yunanta, S. (n.d.). Gerakan Militan Islam di Indonesia dan di Asia Tenggara. Jakarta: Friedrich-Ebert-Stiftung. 